electricity prices (caused by the Polish crisis, which has reduced Hamburg's supply of cheap coal to a trickle) by reducing its operating time to $4 \frac{1}{2}$ months (in 1980 it was 9 months). At present the laboratory is counting on a partial reprieve and working as if it will get 6 months. If it does not - the Bundestag will decide in the spring - it will be quiet in Hamburg later in the year.

Robert Walgate

\section{Soviet agriculture}

\section{Soil first}

Dr Vladimir Borovskii, director of the Kazakh Institute of Soil Science, has strongly criticized the All-Union Academy of Agricultural Sciences for its neglect of soil problems. The academy, he said, has no long-term programmes for studying the nature of the soil and establishing the laws of soil formation.

Interviewed on Moscow radio last month, Dr Borovskii said that unless these shortcomings are put right, the development of Soviet agriculture will inevitably be retarded. The draft basic guidelines for the new Five Year Plan, which are to be presented to the Party Congress later this month, should, he urged, include a clause that soil research must be considerably expanded.

The weeks between the publication of the draft guidelines and the meeting of the Party Congress which will approve them is traditionally a time for constructive criticism. As always, the guidelines emphasized the needs of agriculture.

By 1985 , it is planned that production of mineral fertilizers should reach at least 150 million tonnes annually, at least 115 million tonnes of which will go to Soviet agriculture. A further 3.4-3.6 million hectares of irrigated land and 3.7-3.9 million hectares of drained land are to be brought into use. Some 26-28 million hectares of pasture are to be reclaimed from desert, semi-arid or mountainous regions. There is to be a drive for more efficient use of irrigated or drained land, and improvement of the technical level of water conservancy. Improvements are also expected in reducing the salinity of agricultural water supplies and soil acidity.

Mr Brezhnev clearly had these measures in mind in his message to the All-Union Agronomists' Conference in Moscow last December. Soviet agriculture, he said, had "powerful levers for raising productivity - modern technology, chemical means, large areas of irrigated and drained land, the achievements of science and advanced experience". In a similar vein, Politburo Member Mikhail S. Gorbachev stressed the "profound learning, highly scientific spirit and professional competence of Soviet agronomists". It was when the advice of such experts was ignored, he told the conference, that things began to go wrong.

Gorbachev's main criticisms of Soviet agriculture related mainly to planning.
What was needed, he said, was "a sharper turn of the whole economic, organizational and political work towards effective use of the material, labour and financial resources", the more rational use of land, substantial increases in the production of grain and fodder and "solution of the social problems of the countryside".

Vera Rich

\section{Solar power \\ Crimean costs}

The Soviet Union's first solar power station will go into operation in 1985, according to a "round table" discussion on solar energy published last month in the Moscow weekly Literaturnaya Gazeta. This pilot station, to be built in the Crimea, will have a generating capacity of $5 \mathrm{MW}$, and will run at an estimated cost of 1.5-2 rubles per $\mathrm{kWh}$.

The cost is high. According to the Soviet Ministry of Energy, in 1979 the production cost of $1 \mathrm{kWh}$ was 0.752 kopeks at a conventional thermal station, 0.786 kopeks for nuclear power and 0.149 kopeks for hydroelectricity. Thus the generation cost of Crimean solar electricity will be almost two hundred times that of nuclear power and more than a thousand times that of hydroelectricity.

Nevertheless, the pilot station has an important place in the new Five-Year Plan, which calls for an increase of renewable energy use in the national economy. While maintaining that the Soviet Union runs no risk of a shortage of conventional fossil fuels, energy planners have for several years been insisting on the need to conserve them, stressing their irreplaceable role as feedstocks for industry.

A number of solar energy projects are already under way in the Crimea, which has an average of only 47 days a year without sunshine. These include the Alushta experimental centre, where a village of singlestorey cottages is used to test solarpowered domestic heating/airconditioning units, and an experimental metallurgy centre at Karsiveli where parabolic mirrors will be used to produce temperatures of $3,500^{\circ} \mathrm{C}$, allowing metals to be smelted to a high degree of purity.

The intended solar power station will also use parabolic mirrors, heating water to drive steam generators. Long-term plans for solar energy will take more sophisticated forms. According to Academician Nikolai N. Semenov, academic secretary of the "scientific council for finding new ways of using solar energy", research is being concentrated on photoelectric conversion.

Chemical methods of dissociating water are also being explored, according to Semenov, whose contribution to the round table differed very little from what energy strategists elsewhere are accustomed to say. Semenov emphasized the need for continuing research at a basic level in the exploitation of solar energy. Vera Rich

\section{Wildlife conservation Keepers' charter}

The new British Wildlife and Countryside Bill has accomplished one thing at least - it has attracted a record of 600 amendments for debate in the committee stage in the House of Lords. After two weeks, the number of amendments discussed by the end of last week was well below target. The government still has a long haul ahead.

Most of the amendments dealt with so far have been withdrawn for further consideration by the government, whose views will not be known until the bill emerges from the committee. The government has however agreed even at this early stage to include the red squirrel, now down to a handful of breeding colonies in England, on the list of protected species. Other amendments, which have aroused varying degrees of interest but as yet no firm government response, include protecting bats in private houses, banning the use of crossbows to kill wild animals and protecting badgers and red foxes from the hazards of snares.

The debate is likely to become more fierce later this week, when the House of Lords turns from debating the protection of wild animals and plants (the first part of the bill) to the conservation of the countryside and national parks. The bill includes a clause relating to sites of special scientific interest, designated as such by the Nature Conservancy Council. Voluntary conservation bodies and the council have condemned the draft clause which requires that the owners of only some specially selected sites will have a statutory obligation to give notice of operations that could alter the characteristics of the site.

They argue that all sites should have the same protection and that the singling out of some sites would lower the status of the others. The clause has provoked a spate of amendments, the more extreme of which ask that all agricultural practice should be subject to the planning laws. The strength of opinion is likely to persuade the government to cave in.

Many of the amendments now being tabled could change the status of the Nature Conservancy Council, statutorily responsible for conservation. Not only might the council be given more power in enforcing protection for sites of special scientific interest but, if the voluntary bodies have their way, it could be called upon to help enforce wildlife legislation generally.

The council's reaction to the voluntary bodies' enthusiasm for awarding it greater power is cautious - it says simply that it is primarily a scientific organization. Memories of the bruising battle with the Natural Environment Research Council a decade ago, from which the conservancy council emerged the loser, are still fresh.

Judy Redfearn 